\title{
Hypervalent iodine compounds for anti-Markovnikov-type iodo-oxyimidation of vinylarenes
}

\author{
Igor B. Krylov ${ }^{1,2}$, Stanislav A. Paveliev ${ }^{1}$, Mikhail A. Syroeshkin ${ }^{1}$, \\ Alexander A. Korlyukov ${ }^{3,4}$, Pavel V. Dorovatovskii ${ }^{5}$, Yan V. Zubavichus ${ }^{5}$, \\ Gennady I. Nikishin ${ }^{1}$ and Alexander O. Terent'ev ${ }^{* 1,2}$
}

\section{Full Research Paper}

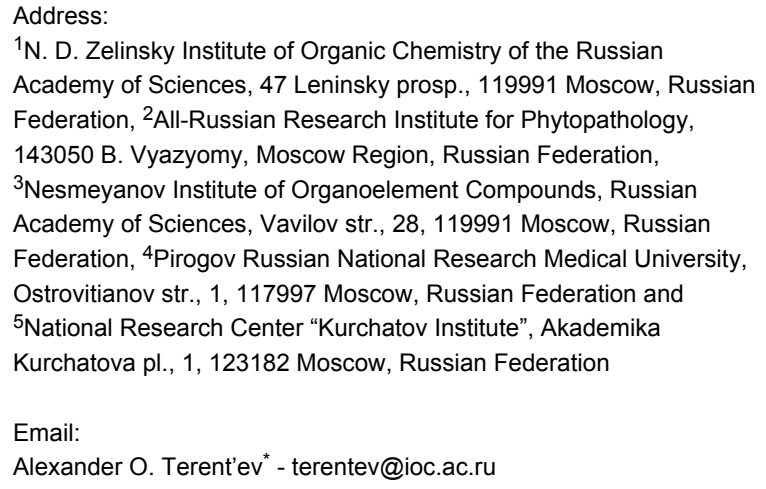

${ }^{1} \mathrm{~N}$. D. Zelinsky Institute of Organic Chemistry of the Russian Academy of Sciences, 47 Leninsky prosp., 119991 Moscow, Russian Federation, ${ }^{2}$ All-Russian Research Institute for Phytopathology, 143050 B. Vyazyomy, Moscow Region, Russian Federation, ${ }^{3}$ Nesmeyanov Institute of Organoelement Compounds, Russian Academy of Sciences, Vavilov str., 28, 119991 Moscow, Russian Federation, ${ }^{4}$ Pirogov Russian National Research Medical University, Ostrovitianov str., 1, 117997 Moscow, Russian Federation and ${ }^{5}$ National Research Center "Kurchatov Institute", Akademika Kurchatova pl., 1, 123182 Moscow, Russian Federation

Email:

Alexander O. Terent'ev ${ }^{*}$ - terentev@ioc.ac.ru

* Corresponding author

\section{Keywords:}

free radicals; hypervalent iodine; imide- $N$-oxyl radicals; iodination; $\mathrm{N}$-hydroxyimides; oxidative functionalization

\begin{abstract} various nucleophiles.

\section{Introduction}

The presented work opens a new chapter in the chemistry of $\mathrm{N}$-hydroxyimides in combination with hypervalent iodine compounds with formation of imide- $N$-oxyl radicals. These radicals were used as reagents for the addition to a terminal position of the double bond of styrenes with subsequent iodination of the resulting benzylic radical.
\end{abstract}

The iodo-oxyimidation of styrenes with the $\mathrm{N}$-hydroxyimide $/ \mathrm{I}_{2} /$ hypervalent iodine oxidant system was proposed. Among the examined hypervalent iodine oxidants (PIDA, PIFA, IBX, DMP) $\mathrm{PhI}(\mathrm{OAc})_{2}$ proved to be the most effective; yields of iodo-oxyimides are $34-91 \%$. A plausible reaction pathway includes the addition of an imide- $N$-oxyl radical to the double $\mathrm{C}=\mathrm{C}$ bond and trapping of the resultant benzylic radical by iodine. It was shown that the iodine atom in the prepared iodo-oxyimides can be substituted by

It is important to note, that nitroxyl radicals are widely used in organic and biological chemistry, and in material design [1-3]. These radicals are applied in the development of monomolecular magnets [4,5], spintronics [2,6], magneto-LC effect studies [7,8], organic voltaic cells [9], electrodes for electrochemical synthesis [2], and as mediators of living polymeriza- 
tion $[10,11]$. In organic synthesis more stable types of $N$-oxyl radicals can be used as carbon-centered radical scavengers [12], oxidation catalysts, mainly for conversion of alcohols to carbonyl compounds [11,13-17]. Less stable imide- $N$-oxyl radicals are used as effective mediators for $\mathrm{CH}$-functionalization with formation of $\mathrm{C}-\mathrm{C}, \mathrm{C}-\mathrm{O}, \mathrm{C}-\mathrm{S}$, and $\mathrm{C}-\mathrm{N}$ bonds $[11,16,18-42]$.

Phthalimide- $N$-oxyl (PINO) is one of the most known imide- $N$ oxyl radicals that is generated from an inexpensive $N$-hydroxyphthalimide (NHPI). This radical was used in various aerobic oxidations of bulk chemicals $[18,19,43,44]$.

In the present work imide- $N$-oxyl radicals were used for the addition to the $\mathrm{C}=\mathrm{C}$ bonds of styrenes with subsequent functionalization of the resulting benzylic radicals.

Recently, the precursors of $N$-oxyl radicals, such as $N$-hydroxyphthalimide (NHPI), N-hydroxysuccinimide (NHSI), $\mathrm{N}$-hydroxybenzotriazole (HOBt) and hydroxamic acids, have been used in the reactions of radical oxygenation of styrenes [45]. Growth of interest is observed concerning the reactions of styrenes with imide- $N$-oxyl radicals, in which the latter add to the terminal position of the double $\mathrm{C}=\mathrm{C}$ bond with the forma- tion of stabilized benzyl radicals, which undergo the subsequent functionalization. In the presence of oxygen or tertbutyl hydroperoxide, oxidation proceeds to form the $\mathrm{C}-\mathrm{O}$ [46-51] or the $\mathrm{C}=\mathrm{O}$ [52-55] moiety. More complex reagents and reaction systems allows to form $\mathrm{C}-\mathrm{C}[56,57]$ and $\mathrm{C}-\mathrm{N}[58,59]$ bonds.

Among the above-mentioned methods, there are no examples of $\mathrm{C}-\mathrm{Hal}$ bond formation despite the wide usage of organohalides in chemical syntheses. In the row of organohalides, iodides are the most reactive and versatile reagents for the following transformations [60].

One of the purposes of our work was to introduce iodine in the process of difunctionalization of styrenes with imide- $N$-oxyl radicals. Iodine atom in the product can act as a versatile leaving group for further transformations. The involvement of the iodine in the radical reactions of styrenes is complicated by the fact that unsaturated compounds readily undergo electrophilic iodination with the addition of an external nucleophile $[61,62]$. The oxidants used for the preparation of imide- $N$-oxyl radicals, in particular the hypervalent iodine compounds and peroxides [63-73], also generate electrophilic iodinating intermediates (Scheme 1).

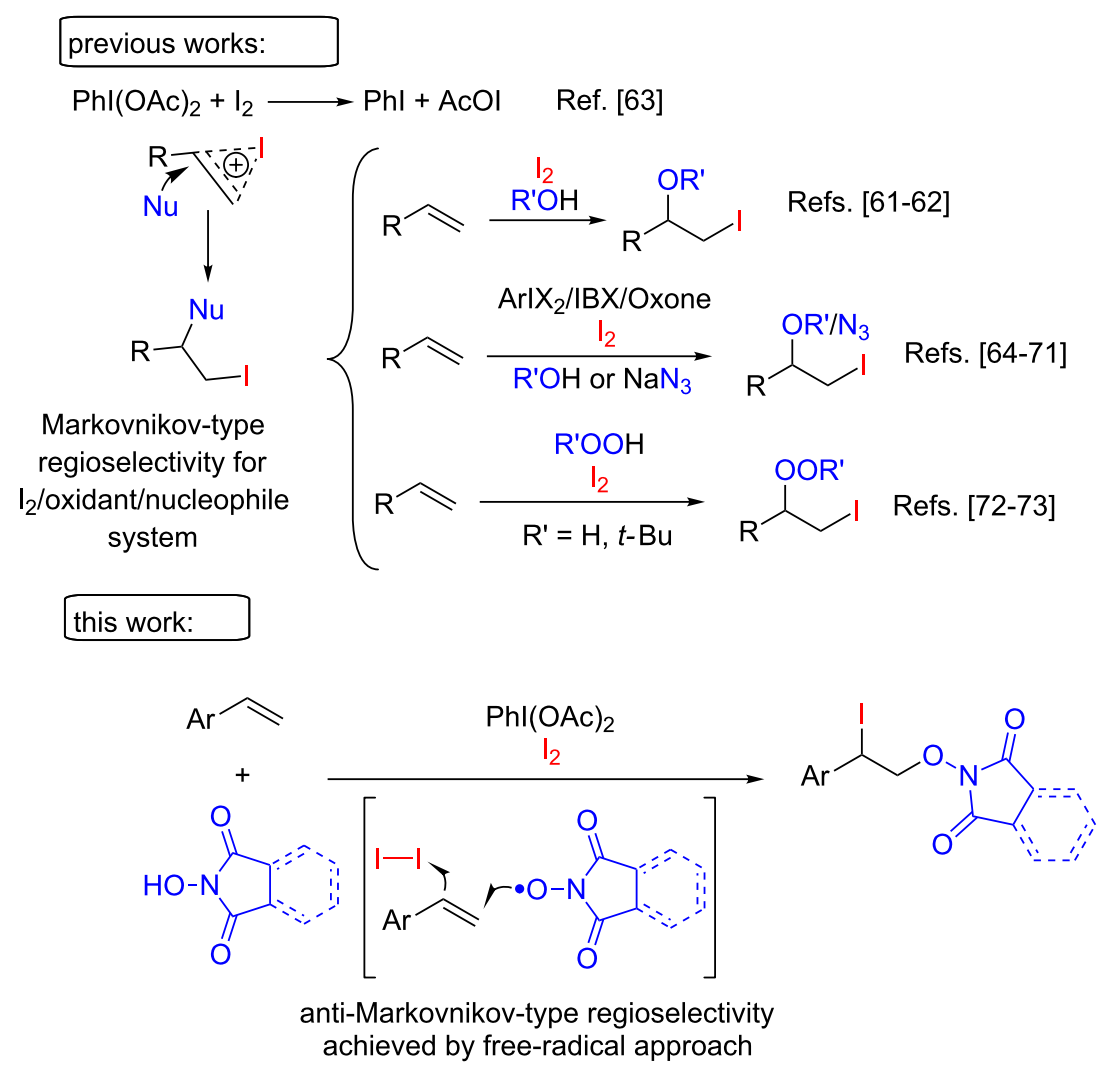

Scheme 1: Difunctionalization of double $\mathrm{C}=\mathrm{C}$ bond with the formation of $\mathrm{C}-\mathrm{O}$ and $\mathrm{C}-\mathrm{I}$ bonds. 
For several decades, a number of papers on the electrophilic iodination of $\mathrm{C}=\mathrm{C}$ bonds by iodine-containing oxidative systems with the addition of various nucleophiles have been published, all of these processes have common mechanism and the same regioselectivity. The free-radical approach developed in the present work affords the opposite (anti-Markovnikov) regioselectivity of the addition to the double bond.

\section{Results and Discussion}

In the present work, the reaction of styrenes $1 \mathbf{a}-\mathbf{k}$ and $\mathrm{N}$-hydroxyimides $\mathbf{2} \mathbf{a}, \mathbf{b}$ with the formation of iodo-oxyimidated products $\mathbf{3 a a}-\mathbf{k a}, \mathbf{3 a b}-\mathbf{d b}, \mathbf{3 f b}, \mathbf{3 h b}$ and $\mathbf{3 k b}$ was carried out (Scheme 2).

The key feature of the developed process is the non-standard regioselectivity of the formation of $\mathrm{C}-\mathrm{I}$ and $\mathrm{C}-\mathrm{O}$ bonds, which implies the radical pathway of the reaction.

The iodo-oxyimidation of styrenes was studied in the model reaction of styrene (1a) with $N$-hydroxyphthalimide (2a). During the optimization, the oxidant and the iodine source, as well as the nature of the solvent and the reaction time were varied (Table 1).

In general, the iodo-oxyimidation reaction is characterized by the following: The product 3aa is formed regardless what kind of hypervalent iodine compound is used (Table 1, entries 1-14) and Oxone (Table 1, entries 15 and 16) as the oxidant. The best yield of 3aa (90\%) was obtained using $\mathrm{PhI}(\mathrm{OAc})_{2}$ (Table 1 , entry 2). Other iodine-based oxidants, such as $\mathrm{PhI}\left(\mathrm{OCOCF}_{3}\right)_{2}$ (Table 1, entry 10, yield 31\%), IBX (Table 1, entries 11 and 12, yield $32-54 \%$ ), DMP (Table 1, entries 13-14, yield 52\%), showed less efficacy in this process. Peroxide oxidants, such as TBHP, TBAI/TBHP system [74], $\left(\mathrm{NH}_{4}\right)_{2} \mathrm{~S}_{2} \mathrm{O}_{8}$, and DDQ were ineffective in the studied process (Table 1, entries 17-22). A satisfactory yield of 3aa (44\%) was achieved using Oxone as the oxidant (Table 1, entry 15). The addition of a catalytic amount of 2-iodobenzoic acid, which forms hypervalent iodine compounds in the presence of Oxone [75], did not lead to an increased yield of 3aa (Table 1, entry 16).

Dichloromethane proved to be the best solvent for the reaction, as carrying out the reaction in other solvents led to a decrease in the yield of 3aa (Table 1, entries 5-7). Increasing the amount of $\mathrm{PhI}(\mathrm{OAc})_{2}$ from $0.6 \mathrm{mmol}$ to $1.5 \mathrm{mmol}$ (Table 1, entry 4) leads to a decrease in the yield of $\mathbf{3 a a}$ presumably due to the enhancing the role of side oxidation processes. The optimal reaction time was $10 \mathrm{~min}$, a reaction of $5 \mathrm{~min}$ resulted in a significant decrease in the yield of the desired product (Table 1, entry 1). Prolongation of the reaction time to $24 \mathrm{~h}$ led to a slight decrease in the yield of $\mathbf{3 a a}$ (Table 1, entry 3 ) due to its instability under the reaction conditions.

The possibility of using iodide salts (NaI and TBAI) was shown in Entries 8 and 9, however, the yield of 3aa in that cases is lower than in the case of molecular iodine.

In the optimized reaction conditions (Table 1, entry 2) iodooxyimidation of various vinylarenes were performed in order to study the scope of the developed method (Figure 1).

The iodo-oxyimidation successfully proceeded using styrenes having both electron-withdrawing $(\mathrm{Cl}, \mathrm{F}, \mathrm{Br})$ substituents in the aromatic ring (products $\mathbf{3 c a}, \mathbf{3 d a}, \mathbf{3 f a}, \mathbf{3 h a}, \mathbf{3} \mathbf{c b}-\mathbf{h b}$,

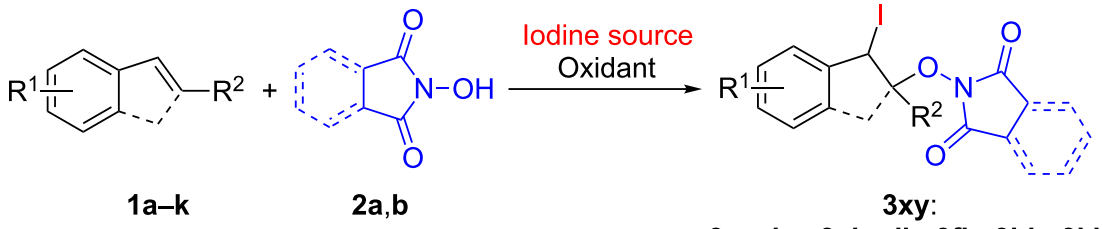

1a: $\mathrm{R}^{1}=\mathrm{H}, \mathrm{R}^{2}=\mathrm{H} ; \quad$ 2a: $N$-hydroxyphthalimide; 1b: $\mathrm{R}^{1}=p-\mathrm{Me}, \mathrm{R}^{2}=\mathrm{H} ; \quad \mathbf{2 b}: N$-hydroxysuccinimide 1c: $\mathrm{R}^{1}=p-\mathrm{Cl}, \mathrm{R}^{2}=\mathrm{H}$;

1d: $\mathrm{R}^{1}=p-\mathrm{F}, \mathrm{R}^{2}=\mathrm{H}$;

1e: $\mathrm{R}^{1}=m-\mathrm{Me}, \mathrm{R}^{2}=\mathrm{H}$;

1f: $\mathrm{R}^{1}=m-\mathrm{Br}, \mathrm{R}^{2}=\mathrm{H}$;

1g: $\mathrm{R}^{1}=\mathrm{o}-\mathrm{Me}, \mathrm{R}^{2}=\mathrm{H}$;

1h: $R^{1}=$ perfluoro, $R^{2}=H$;

1i: $R^{1}=H, R^{2}=M e$;

1j: $R^{1}=H, R^{2}=P h$;

1k: indene
$3 a a-k a, 3 a b-d b, 3 f b, 3 h b, 3 k b$

the first letter $(x)$ stands for the employed vinyl arene $\mathbf{1} \mathbf{a}-\mathbf{k}$, the second letter $(y)$ - imide $\mathbf{2} \mathbf{a}, \mathbf{b}$ 
Table 1: Optimization of the synthesis of iodo-oxyimidation product $3 \mathbf{a}$ from styrene $1 \mathbf{a}$ and $N$-hydroxyimide $2 a^{a}$.

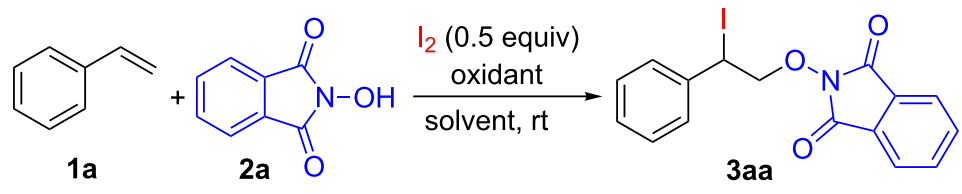

\begin{tabular}{|c|c|c|c|c|}
\hline entry & oxidant (molar ratio: mol/mol of 1a) & solvent & time & yield of $3 a a^{b}(\%)$ \\
\hline 1 & $\mathrm{Phl}(\mathrm{OAc})_{2}(0.6)$ & DCM & $5 \min$ & 63 \\
\hline 2 & $\mathrm{Phl}(\mathrm{OAc})_{2}(0.6)$ & DCM & $10 \min$ & 90 \\
\hline 3 & $\mathrm{Phl}(\mathrm{OAc})_{2}(0.6)$ & DCM & $24 \mathrm{~h}$ & 84 \\
\hline 4 & $\mathrm{Phl}(\mathrm{OAc})_{2}(1.5)$ & DCM & $10 \min$ & 73 \\
\hline 5 & $\mathrm{Phl}(\mathrm{OAc})_{2}(0.6)$ & $\mathrm{MeCN}$ & $10 \min$ & 73 \\
\hline 6 & $\mathrm{Phl}(\mathrm{OAc})_{2}(0.6)$ & $\mathrm{AcOH}$ & $10 \min$ & 65 \\
\hline 7 & $\mathrm{Phl}(\mathrm{OAc})_{2}(0.6)$ & PhMe & $10 \min$ & 84 \\
\hline $8^{c}$ & $\mathrm{Phl}(\mathrm{OAc})_{2}(2)$ & DCM & $10 \min$ & 7 \\
\hline $9^{d}$ & $\mathrm{Phl}(\mathrm{OAc})_{2}(2)$ & DCM & $10 \min$ & 52 \\
\hline 10 & $\mathrm{Phl}\left(\mathrm{OCOCF}_{3}\right)_{2}(0.6)$ & $\mathrm{DCM}$ & $10 \min$ & 31 \\
\hline 11 & $\mathrm{IBX}(1.0)$ & $\mathrm{DCM}$ & $24 \mathrm{~h}$ & 54 \\
\hline 12 & $\mathrm{IBX}(0.3)$ & DCM & $24 \mathrm{~h}$ & 32 \\
\hline 13 & DMP (0.6) & DCM & $30 \mathrm{~min}$ & 52 \\
\hline 14 & DMP (0.3) & DCM & $30 \min$ & 52 \\
\hline 15 & Oxone (2) & $\mathrm{DCM} / \mathrm{H}_{2} \mathrm{O}(2: 1)$ & $4 \mathrm{~h}$ & 44 \\
\hline 16 & 2-iodobenzoic acid (0.1), Oxone (2) & $\mathrm{DCM} / \mathrm{H}_{2} \mathrm{O}(2: 1)$ & $4 \mathrm{~h}$ & 44 \\
\hline 17 & TBHP (70\% aq) (2) & $\mathrm{DCM}$ & $12 \mathrm{~h}$ & ND \\
\hline 18 & TBHP (70\% aq) (2) & $\mathrm{MeCN}$ & $12 \mathrm{~h}$ & ND \\
\hline 19 & TBHP (70\% aq) (2) & $\mathrm{AcOH}$ & $12 \mathrm{~h}$ & ND \\
\hline 20 & TBAI (0.1), TBHP (70\% aq) (2) & $\mathrm{MeCN}$ & $12 \mathrm{~h}$ & ND \\
\hline 21 & $\left(\mathrm{NH}_{4}\right)_{2} \mathrm{~S}_{2} \mathrm{O}_{8}(1.5)$ & $\mathrm{DCM} / \mathrm{H}_{2} \mathrm{O}(2: 1)$ & $12 \mathrm{~h}$ & 5 \\
\hline 22 & DDQ (2) & $\mathrm{MeCN}$ & $30 \min$ & 5 \\
\hline
\end{tabular}

${ }^{a}$ Reaction conditions: $1 \mathrm{a}(1 \mathrm{mmol}), 2 \mathrm{a}(1 \mathrm{mmol}), \mathrm{I}_{2}(0.5 \mathrm{mmol})$, oxidant $(0.3-2 \mathrm{mmol})$, solvent $(6.0 \mathrm{~mL}), 20-25^{\circ} \mathrm{C}, 5 \mathrm{~min}-24 \mathrm{~h}, \mathrm{under}$ air. For entries where a mixture of solvents was used, the $\mathrm{v} / \mathrm{v}$ ratio is given in parentheses. ${ }^{\mathrm{b}}$ lsolated yield. $\mathrm{ND}=$ not detected. ${ }^{\mathrm{C}} \mathrm{Nal} \cdot 2 \mathrm{H}_{2} \mathrm{O}(1 \mathrm{mmol}) \mathrm{was}$ employed instead of $\mathrm{I}_{2}$. $\mathrm{d}$ TBAI $(1 \mathrm{mmol})$ was employed instead of $\mathrm{I}_{2}$.

yield 34-91\%), and an electron-donating methyl group (products 3ba, 3ea, 3ga, 3bb, yield 39-85\%). Good yields (60-79\%) were achieved with a cyclic analogue of styrene - indene $(\mathbf{1 k}$, compounds 3ka, 3kb). $\beta$-Substituted styrenes ( $\beta$-methyl styrene (1i) and $(E)$-stilbene $(\mathbf{1 j})$ also underwent the studied transformation giving iodo-oxyimides $\mathbf{3 i a}$ (yield $51 \%$ ) and $\mathbf{3 j a}$ (yield $83 \%$ ). The reaction of NHPI (2a) with $p$-methoxystyrene under standard conditions led to a complex mixture of products, possibly due to an increased tendency of the substrate to electrophilic addition of iodine. The use of allylbenzene in the reaction did not result in the formation of the desired iodooxyimide, presumably due to a side process of oxidation of the allylic methylene fragment. The use of $N$-hydroxyphthalimide (2a) gives iodo-oxymidation products with yields generally higher $(25 \%$ on average) than that of $N$-hydroxysuccinimide (2b).
Structures of the iodo-oxyimides $\mathbf{3} \mathbf{a a}-\mathbf{k a}, \mathbf{3 a b}-\mathbf{d b}, \mathbf{3 f b}, \mathbf{3 h b}$ and $3 \mathbf{k b}$ were confirmed by 1D and 2D NMR spectroscopy, IR spectroscopy, high-resolution mass spectrometry and elemental analysis. An additional confirmation of the structure of 3ca was made using X-ray crystallographic analysis (Figure 2). Details of the data collection and refinement are provided in Supporting Information File 1 and can be obtained free of charge via the web at https://www.ccdc.cam.ac.uk/structures/ (CCDC-1845323).

\section{Proposed mechanism of the iodo-oxyimidation}

Based on the literature data describing the formation of the phthalimide- $N$-oxyl radical (PINO) from NHPI under the action of $\mathrm{PhI}(\mathrm{OAc})_{2}$ [34,55,59,76,77], and based on information about the reaction of the PINO radical with styrenes [45] and interac- 
<smiles>O=C1c2ccccc2C(=O)N1OCC(I)c1ccccc1</smiles>

3aa, $90 \%$<smiles>O=C1c2ccccc2C(=O)N1OCC(I)c1ccc(F)cc1</smiles>

3da, $77 \%$<smiles>Cc1ccccc1C(I)CON1C(=O)c2ccccc2C1=O</smiles>

3ga, $87 \%\left(67 \%^{a}, 42 \%{ }^{b}\right)$<smiles>O=C1c2ccccc2C(=O)N1OC(c1ccccc1)c1ccccc1</smiles>

3ja, $83 \%, d r=1.8: 1$<smiles>Cc1ccc(C(I)CON2C(=O)CCC2=O)cc1</smiles>

3bb, $39 \%$<smiles>O=C1CCC(=O)N1OCC(I)c1cccc(Br)c1</smiles>

3fb, $34 \%$<smiles>Cc1ccc(C(I)CON2C(=O)c3ccccc3C2=O)cc1</smiles>

3ba, $81 \%, r r=4: 1$<smiles>Cc1cccc(C(I)CON2C(=O)c3ccccc3C2=O)c1</smiles>

3ea, $85 \%$<smiles>O=C1c2ccccc2C(=O)N1OCC(I)c1c(F)c(F)c(F)c(F)c1F</smiles>

3ha, $63 \%$<smiles>O=C1c2ccccc2C(=O)N1O[C@H]1Cc2ccccc2C1I</smiles>

3ka, $79 \%$<smiles>O=C1CCC(=O)N1OCC(I)c1ccc(Cl)cc1</smiles>

$3 \mathrm{cb}, 61 \%$<smiles>O=C1CCC(=O)N1OCC(I)c1c(F)c(F)c(F)c(F)c1F</smiles>

3hb, $60 \%$<smiles>O=C1c2ccccc2C(=O)N1OCC(I)c1ccc(Cl)cc1</smiles>

3ca, $91 \%\left(81 \%^{\mathrm{a}}, 30 \%^{\mathrm{b}}\right)$<smiles>O=C1c2ccccc2C(=O)N1OCC(I)c1cccc(Oc2ccccc2)c1</smiles>

3fa, $79 \%$<smiles>CC(ON1C(=O)c2ccccc2C1=O)C(I)c1ccccc1</smiles>

3ia, $51 \%, d r=1: 1$<smiles>O=C1CCC(=O)N1OCC(I)c1ccccc1</smiles>

3ab, $67 \%$<smiles>O=C1CCC(=O)N1OCC(I)c1ccc(F)cc1</smiles>

$3 \mathrm{db}, 63 \%$<smiles>O=C1CCC(=O)N1O[C@H]1Cc2ccccc2C1I</smiles>

3kb, $60 \%$

Figure 1: Scope of the iodo-oxyimidation of vinylarenes with $\mathrm{I}_{2} / \mathrm{Phl}(\mathrm{OAc})_{2}$ system. Reaction conditions: vinylarene $1 \mathrm{a}-\mathbf{k}(0.5 \mathrm{mmol}), \mathrm{N}$-hydroxyimide 2a,b $(0.5 \mathrm{mmol}), \mathrm{I}_{2}(0.25 \mathrm{mmol}), \mathrm{Phl}(\mathrm{OAc})_{2}(0.3 \mathrm{mmol}), \mathrm{DCM}(3.0 \mathrm{~mL}), 20-25{ }^{\circ} \mathrm{C}, 10 \mathrm{~min}$, under air. rr = regioisomers ratio. ${ }^{a} \mathrm{IBX}(0.5 \mathrm{mmol})$ was used instead of $\mathrm{Phl}(\mathrm{OAc})_{2}$, reaction time: $24 \mathrm{~h}$. ${ }^{\mathrm{b}} \mathrm{DMP}(0.15 \mathrm{mmol})$ was used instead of $\mathrm{Phl}(\mathrm{OAc})_{2}$, reaction time $30 \mathrm{~min}$.

tion of benzyl radicals with iodine [78,79], a mechanism for the reaction of iodo-oxyimidation of styrenes under the action of the $\mathrm{NHPI} / \mathrm{I}_{2} / \mathrm{PhI}(\mathrm{OAc})_{2}$ system was proposed (Scheme 3).

On the first step, NHPI (2a) is oxidized by $\mathrm{PhI}(\mathrm{OAc})_{2}$ to form PINO radical. The addition of PINO to the double $\mathrm{C}=\mathrm{C}$ bond of styrene (1a) leads to the formation of intermediate $\mathbf{A}$. At the final step the iodine traps benzyl radical $\mathbf{A}$ to form the final product 3aa.

\section{Electrochemical studies}

Cyclic voltammetry (CV) experiments on a working glassy-carbon electrode were carried out for deeper understanding of the plausible reaction mechanism. As $\mathrm{CH}_{2} \mathrm{Cl}_{2}$ is not suitable as a solvent due to the poor solubility of NHPI, thus MeCN was used. Tetrabutylammonium tetrafluoroborate, which cannot be oxidized in such experimental conditions [80], was chosen as a supporting electrolyte. Cyclic voltammograms of styrene (1a), NHPI (2a), $\mathrm{I}_{2}$ and $\mathrm{PhI}(\mathrm{OAc})_{2}$ in $\mathrm{MeCN}$ solution were registered (Figure 3 ). 


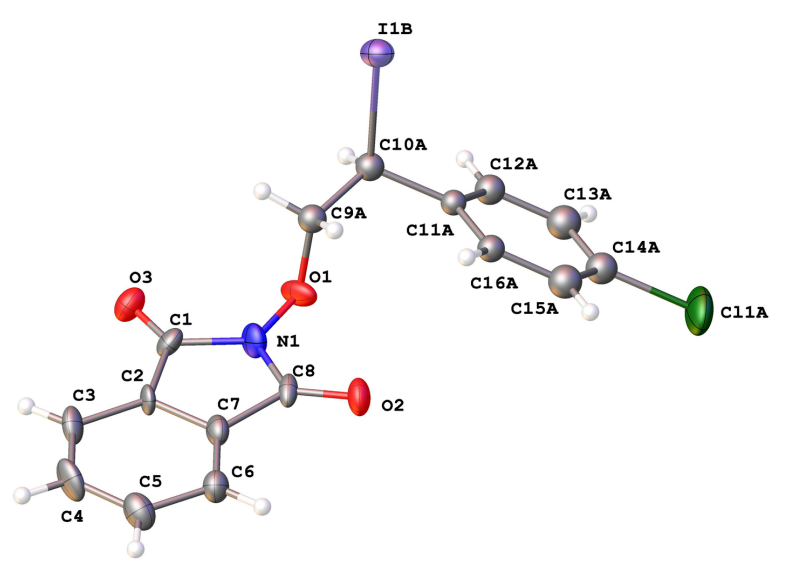

Figure 2: Molecular structure of 3ca. Atoms are presented as anisotropic displacement parameters (ADP) ellipsoids $(50 \%$ probability). For clarity, only one set of positions of the disordered ethylene bridge and $\mathrm{Ph}$ groups is shown.
The NHPI oxidation peak is observed at $+2.18 \mathrm{~V}$, whereas iodine is oxidized at slightly higher potential $(+2.27 \mathrm{~V})$, and styrene oxidation peak is not so pronounced. Therefore, we can conclude that under experimental conditions NHPI is oxidized preferentially over iodine providing PINO radicals that leads to the observed regioselectivity. The contribution of the oxidation of styrene to the overall process is unlikely.

\section{Practical application of the iodo-oxyimidation}

The applicability of the developed method for the gram-scale preparation was demonstrated by the synthesis of 3aa (3.1 g, $79 \%$ ) without column chromatography (Scheme 4).

The synthetic utility of the obtained products 3aa and 3ab was demonstrated by the substitution of the iodine atom with O- (methanol), S- (benzenesulfinate) and N- (azide) nucleophiles (Scheme 5).

It is noteworthy that the reaction of compound 3aa with sodium benzenesulfinate results in the nucleophilic substitution of<smiles>C=Cc1ccccc1CCON1C(=O)c2ccc(C(=O)ON3C(=O)c4ccccc4C3=O)cc2C1c1ccc(CCON2C(=O)c3ccccc3C2=O)cc1</smiles><smiles>O=C1c2ccccc2C(=O)N1O</smiles>

$10 \mathrm{mmol}, 1.04 \mathrm{~g} 10 \mathrm{mmol}, 1.63 \mathrm{~g}$
$\mathrm{I}_{2}(5 \mathrm{mmol}, 1.27 \mathrm{~g})$ $\mathrm{Phl}(\mathrm{OAc})_{2}(6 \mathrm{mmol}, 1.94 \mathrm{~g})$ DCM, rt, 10 min<smiles>O=C1c2ccccc2C(=O)N1OCC(I)c1ccccc1</smiles>

3aa

yield after recrystallization: $79 \%(3.1 \mathrm{~g})$ 


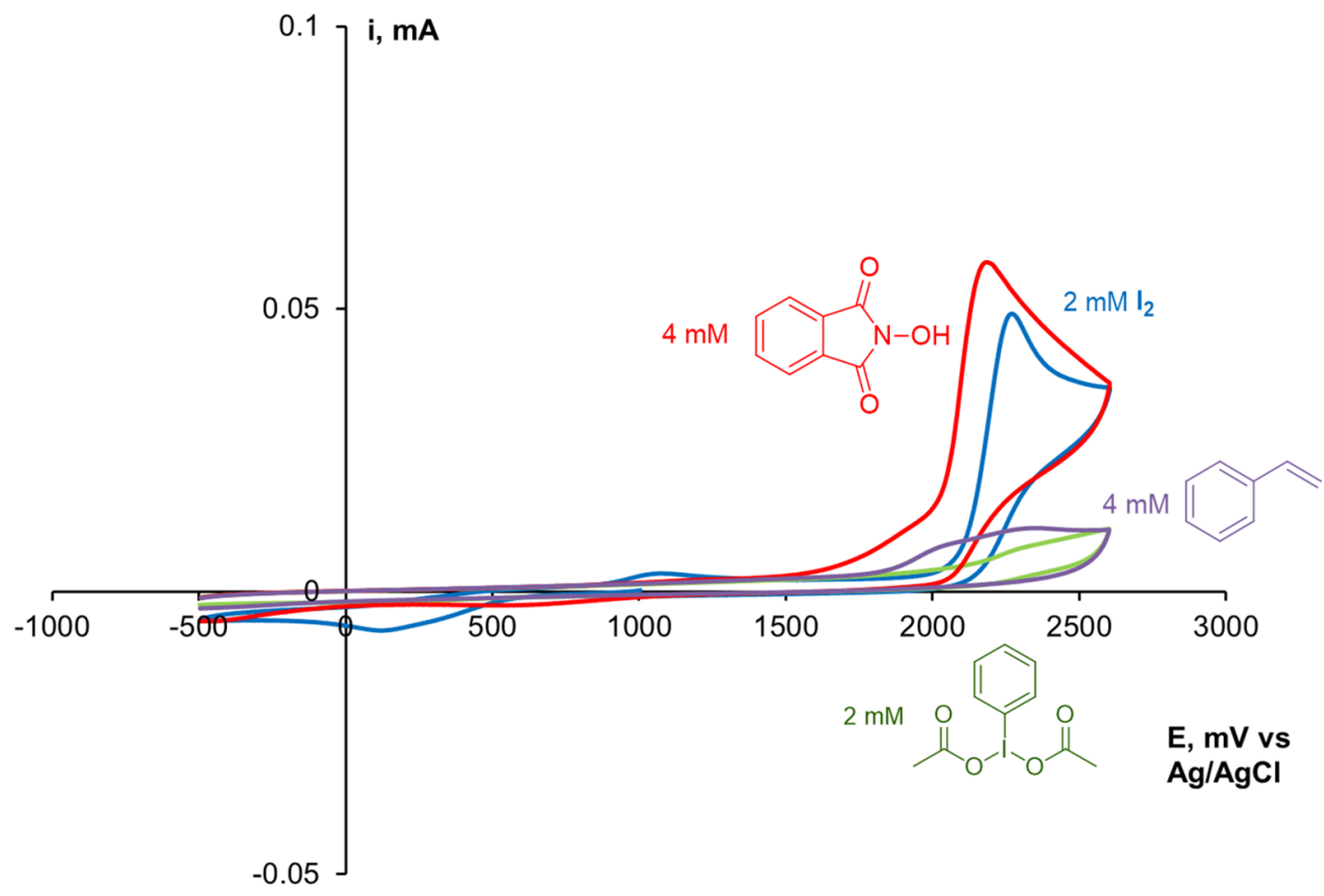

Figure 3: CV curves of styrene (1a, purple), NHPI (2a, red), $\mathrm{I}_{2}$ (blue) and $\mathrm{Phl}(\mathrm{OAc})_{2}$ (green) in $0.1 \mathrm{M} \mathrm{n}-\mathrm{Bu}_{4} \mathrm{NBF}_{4} / \mathrm{MeCN}$ at a scan rate of $100 \mathrm{mV} / \mathrm{s}$ on a working glassy-carbon electrode.

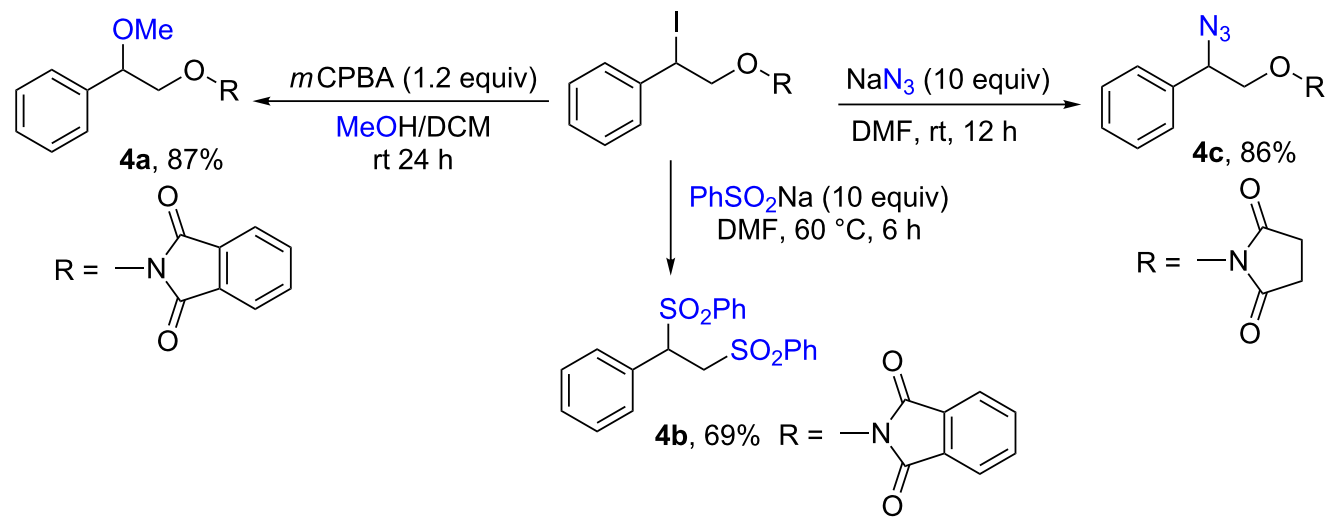

Scheme 5: Synthetic utility of the iodo-oxyimides 3aa and 3ab.

both the iodine atom and the oxyphthalimide moiety to form a vicinal disulfone $\mathbf{4 b}$.

\section{Conclusion}

Iodo-oxyimidation of vinylarenes using $N$-hydroxyphthalimide and $N$-hydroxysuccinimide was developed. $\mathrm{PhI}(\mathrm{OAc})_{2}$ was the best oxidant for the synthesis of the target products (yields up to
$91 \%$ ). In contrast to previous studies in which oxidants promote the electrophilic addition of iodine to the $\mathrm{C}=\mathrm{C}$ bond, radical addition predominates in the discovered process. Radical pathway starts from the attack of imide- $N$-oxyl radicals on the double $\mathrm{C}=\mathrm{C}$ bond, which allows for antiMarkovnikov type regioselectivity of $\mathrm{C}-\mathrm{O}$ and $\mathrm{C}-\mathrm{I}$ bond formation. Electrochemical mechanistic studies based 
on cyclic voltammetry $(\mathrm{CV})$ data confirm proposed reaction mechanism. Possible ways of using the obtained iodo-oxyimidated products via substitution of iodine atom were demonstrated.

\section{Experimental}

\section{General procedure for the synthesis of} compounds $3 \mathbf{a a}-\mathbf{k a}, \mathbf{3 a b}-\mathrm{db}, \mathbf{3 f b}, \mathbf{3 h b}$ and

\section{$\mathbf{3 k b}$ (Figure 1)}

Iodine (64 mg, $0.25 \mathrm{mmol}$ ) was added to a stirred mixture of vinylarene 1a-k (52-97 mg, $0.50 \mathrm{mmol})$ and $N$-hydroxyimide 2a,b (58-82 mg, $0.50 \mathrm{mmol})$ in $\mathrm{CH}_{2} \mathrm{Cl}_{2}(3 \mathrm{~mL})$ at $20-25^{\circ} \mathrm{C}$. Then, $\mathrm{PhI}(\mathrm{OAc})_{2}(97 \mathrm{mg}, 0.30 \mathrm{mmol})$ was added. In the additional experiments compounds $\mathbf{3} \mathbf{c a}$ and $\mathbf{3 g a}$ were prepared using IBX (140 mg, $0.50 \mathrm{mmol}$ ) or DMP (64 mg, $0.15 \mathrm{mmol}$ ) instead of $\mathrm{PhI}(\mathrm{OAc})_{2}$. After stirring for $10 \mathrm{~min}$ under air atmosphere at $20-25{ }^{\circ} \mathrm{C}, \mathrm{CH}_{2} \mathrm{Cl}_{2}(30 \mathrm{~mL})$ was added. The resulting mixture was washed with an aqueous solution of $\mathrm{Na}_{2} \mathrm{~S}_{2} \mathrm{O}_{3} \cdot 5 \mathrm{H}_{2} \mathrm{O}$ ( $200 \mathrm{mg}$ in $20 \mathrm{~mL}$ of water), saturated aqueous $\mathrm{NaHCO}_{3}$ solution $(20 \mathrm{~mL})$, and with water $(20 \mathrm{~mL})$, dried over anhydrous $\mathrm{MgSO}_{4}$ and filtered. $\mathrm{CH}_{2} \mathrm{Cl}_{2}$ was evaporated at $20-25^{\circ} \mathrm{C}$ under water-jet vacuum (20-30 mm Hg). Products 3aa-ka, 3ab-db, $\mathbf{3 f b}, \mathbf{3 h b}$ and $\mathbf{3 k b}$ were isolated by column chromatography on silica gel using with EtOAc/DCM eluent (with the volume part of EtOAc gradually increased from $0 \%$ to $2.5 \%$ ).

Iodo-oxyimides 3aa-ka, 3ab-db, 3fb, $\mathbf{3 h b}$ and $\mathbf{3 k b}$ should be stored in a freezer and handled with minimal heat due to their instability at elevated temperatures.

\section{Supporting Information}

\section{Supporting Information File 1}

Experimental procedures, characterization data, copies of ${ }^{1} \mathrm{H},{ }^{13} \mathrm{C}$ and ${ }^{19} \mathrm{~F}$ NMR spectra, copies of HRMS and FT-IR spectra and the ORTEP diagram and X-ray data for compound 3ca.

[https://www.beilstein-journals.org/bjoc/content/ supplementary/1860-5397-14-188-S1.pdf]

\section{Supporting Information File 2}

X-ray structure analysis data for 3ca (CCDC-1845323).

[https://www.beilstein-journals.org/bjoc/content/

supplementary/1860-5397-14-188-S2.cif]

\section{Acknowledgements}

This work was supported by the Russian Science Foundation (18-13-00027).

\section{ORCID ${ }^{\circledR}$ iDs}

Igor B. Krylov - https://orcid.org/0000-0001-7138-7319 Stanislav A. Paveliev - https://orcid.org/0000-0003-1668-9693 Yan V. Zubavichus - https://orcid.org/0000-0003-2266-8944 Alexander O. Terent'ev - https://orcid.org/0000-0001-8018-031X

\section{References}

1. Hicks, R. G. Org. Biomol. Chem. 2007, 5, 1321. doi:10.1039/b617142g

2. Mas-Torrent, M.; Crivillers, N.; Rovira, C.; Veciana, J. Chem. Rev. 2012, 112, 2506. doi:10.1021/cr200233g

3. Berliner, L. J. History of the Use of Nitroxides (Aminoxyl Radicals) in Biochemistry: Past, Present and Future of Spin Label and Probe Method. In Nitroxides - Theory, Experiment and Applications; Kokorin, A. I., Ed.; InTech: Croatia, 2012; pp 3-24.

4. Tretyakov, E. V.; Ovcharenko, V. I. Russ. Chem. Rev. 2009, 78, 971. doi:10.1070/RC2009v078n11ABEH004093

5. Train, C.; Norel, L.; Baumgarten, M. Coord. Chem. Rev. 2009, 253, 2342. doi:10.1016/j.ccr.2008.10.004

6. Sugawara, T.; Komatsu, H.; Suzuki, K. Chem. Soc. Rev. 2011, 40, 3105. doi:10.1039/c0cs00157k

7. Suzuki, K.; Uchida, Y.; Tamura, R.; Shimono, S.; Yamauchi, J. J. Mater. Chem. 2012, 22, 6799. doi:10.1039/c2jm16278d

8. Uchida, Y.; Suzuki, K.; Tamura, R. J. Phys. Chem. B 2012, 116, 9791. doi:10.1021/jp301930k

9. Suga, T.; Konishi, H.; Nishide, H. Chem. Commun. 2007, 1730. doi:10.1039/b618710b

10. Hawker, C. J.; Bosman, A. W.; Harth, E. Chem. Rev. 2001, 101, 3661. doi:10.1021/cr990119u

11. Tebben, L.; Studer, A. Angew. Chem., Int. Ed. 2011, 50, 5034 doi:10.1002/anie.201002547

12. Bagryanskaya, E. G.; Marque, S. R. A. Chem. Rev. 2014, 114, 5011. doi:10.1021/cr4000946

13. Ciriminna, R.; Pagliaro, M. Org. Process Res. Dev. 2010, 14, 245. doi:10.1021/op900059x

14. Hamada, S.; Furuta, T.; Wada, Y.; Kawabata, T. Angew. Chem., Int. Ed. 2013, 52, 8093. doi:10.1002/anie.201302261

15. Ryland, B. L.; Stahl, S. S. Angew. Chem., Int. Ed. 2014, 53, 8824. doi:10.1002/anie.201403110

16. Wertz, S.; Studer, A. Green Chem. 2013, 15, 3116. doi:10.1039/c3gc41459k

17. Muramatsu, W.; Nakano, K. Org. Lett. 2015, 17, 1549. doi:10.1021/acs.orglett.5b00434

18. Recupero, F.; Punta, C. Chem. Rev. 2007, 107, 3800. doi:10.1021/cr040170k

19. Galli, C.; Gentili, P.; Lanzalunga, O. Angew. Chem., Int. Ed. 2008, 47, 4790. doi:10.1002/anie.200704292

20. Wentzel, B. B.; Donners, M. P. J.; Alsters, P. L.; Feiters, M. C.; Nolte, R. J. M. Tetrahedron 2000, 56, 7797. doi:10.1016/s0040-4020(00)00679-7

21. Amaoka, Y.; Kamijo, S.; Hoshikawa, T.; Inoue, M. J. Org. Chem. 2012, 77, 9959. doi:10.1021/jo301840e

22. Sakaguchi, S.; Hirabayashi, T.; Ishii, Y. Chem. Commun. 2002, 516. doi:10.1039/b110638d

23. Sakaguchi, S.; Eikawa, M.; Ishii, Y. Tetrahedron Lett. 1997, 38, 7075 doi:10.1016/s0040-4039(97)01652-3

24. Ishii, Y.; Iwahama, T.; Sakaguchi, S.; Nakayama, K.; Nishiyama, Y. J. Org. Chem. 1996, 61, 4520. doi:10.1021/jo951970l 
25. Minisci, F.; Punta, C.; Recupero, F. J. Mol. Catal. A: Chem. 2006, 251, 129. doi:10.1016/j.molcata.2006.02.011

26. Lee, J. M.; Park, E. J.; Cho, S. H.; Chang, S. J. Am. Chem. Soc. 2008, 130, 7824. doi:10.1021/ja8031218

27. Terent'ev, A. O.; Krylov, I. B.; Sharipov, M. Y.; Kazanskaya, Z. M.; Nikishin, G. I. Tetrahedron 2012, 68, 10263. doi:10.1016/j.tet.2012.10.018

28. Terent'ev, A. O.; Krylov, I. B.; Timofeev, V. P.; Starikova, Z. A.; Merkulova, V. M.; llovaisky, A. I.; Nikishin, G. I. Adv. Synth. Catal. 2013, 355, 2375. doi:10.1002/adsc.201300341

29. Krylov, I. B.; Vil', V. A.; Terent'ev, A. O. Beilstein J. Org. Chem. 2015, 11, 92. doi:10.3762/bjoc.11.13

30. Ananikov, V. P.; Eremin, D. B.; Yakukhnov, S. A.; Dilman, A. D.; Levin, V. V.; Egorov, M. P.; Karlov, S. S.; Kustov, L. M.; Tarasov, A. L.; Greish, A. A.; Shesterkina, A. A.; Sakharov, A. M.; Nysenko, Z. N.; Sheremetev, A. B.; Stakheev, A. Y.; Mashkovsky, I. S.; Sukhorukov, A. Y.; loffe, S. L.; Terent'ev, A. O.; Vil', V. A.; Tomilov, Y. V.; Novikov, R. A.; Zlotin, S. G.; Kucherenko, A. S.; Ustyuzhanina, N. E.; Krylov, V. B.; Tsvetkov, Y. E.; Gening, M. L.; Nifantiev, N. E. Mendeleev Commun. 2017, 27, 425. doi:10.1016/j.mencom.2017.09.001

31. Krylov, I. B.; Paveliev, S. A.; Shelimov, B. N.; Lokshin, B. V.; Garbuzova, I. A.; Tafeenko, V. A.; Chernyshev, V. V.; Budnikov, A. S.; Nikishin, G. I.; Terent'ev, A. O. Org. Chem. Front. 2017, 4, 1947. doi:10.1039/c7qo00447h

32. Guo, Z.; Jin, C.; Zhou, J.; Su, W. RSC Adv. 2016, 6, 79016. doi:10.1039/c6ra14697j

33. Lv, Y.; Sun, K.; Wang, T.; Li, G.; Pu, W.; Chai, N.; Shen, H.; Wu, Y. RSC Adv. 2015, 5, 72142. doi:10.1039/c5ra12691f

34. Qian, P.-C.; Liu, Y.; Song, R.-J.; Hu, M.; Yang, X.-H.; Xiang, J.-N.; Li, J.-H. Eur. J. Org. Chem. 2015, 1680. doi:10.1002/ejoc.201403616

35. Dian, L.; Wang, S.; Zhang-Negrerie, D.; Du, Y. Adv. Synth. Catal. 2015, 357, 3836. doi:10.1002/adsc. 201500623

36. Dinda, M.; Bose, C.; Ghosh, T.; Maity, S. RSC Adv. 2015, 5, 44928. doi:10.1039/c5ra05719a

37. Guo, Z.; Jiang, X.; Jin, C.; Zhou, J.; Sun, B.; Su, W. Synlett 2017, 28, 1321. doi:10.1055/s-0036-1588760

38. Lv, Y.; Sun, K.; Pu, W.; Mao, S.; Li, G.; Niu, J.; Chen, Q.; Wang, T. RSC Adv. 2016, 6, 93486. doi:10.1039/c6ra22653a

39. Tan, B.; Toda, N.; Barbas, C. F., III. Angew. Chem., Int. Ed. 2012, 51, 12538. doi:10.1002/anie.201205921

40. Xu, X.; Li, P.; Huang, Y.; Tong, C.; Yan, Y.; Xie, Y. Tetrahedron Lett. 2017, 58, 1742. doi:10.1016/j.tetlet.2017.03.064

41. Xu, X.; Sun, J.; Lin, Y.; Cheng, J.; Li, P.; Yan, Y.; Shuai, Q.; Xie, Y. Org. Biomol. Chem. 2017, 15, 9875. doi:10.1039/C7OB02249B

42. Siddaraju, Y.; Prabhu, K. R. Org. Biomol. Chem. 2015, 13, 11651. doi:10.1039/C5OB01929J

43. Kompanets, M. O.; Kushch, O. V.; Litvinov, Y. E.; Pliekhov, O. L.; Novikova, K. V.; Novokhatko, A. O.; Shendrik, A. N.; Vasilyev, A. V.; Opeida, I. O. Catal. Commun. 2014, 57, 60. doi:10.1016/j.catcom.2014.08.005

44. Kasperczyk, K.; Orlińska, B.; Zawadiak, J. Cent. Eur. J. Chem. 2014, 12, 1176. doi:10.2478/s11532-014-0565-8

45. Bag, R.; De, P. B.; Pradhan, S.; Punniyamurthy, T. Eur. J. Org. Chem. 2017, 5424. doi:10.1002/ejoc.201700512

46. Xia, X.-F.; Zhu, S.-L.; Hu, Q.-T.; Chen, C. Tetrahedron 2016, 72, 8000. doi:10.1016/j.tet.2016.10.029

47. Bag, R.; Sar, D.; Punniyamurthy, T. Org. Biomol. Chem. 2016, 14, 3246. doi:10.1039/c6ob00210b
48. Yamamoto, D.; Soga, M.; Ansai, H.; Makino, K. Org. Chem. Front. 2016, 3, 1420. doi:10.1039/c6qo00318d

49. Luo, J.; Zhang, J. J. Org. Chem. 2016, 81, 9131. doi:10.1021/acs.joc.6b01704

50. Samanta, S.; Ravi, C.; Joshi, A.; Pappula, V.; Adimurthy, S. Tetrahedron Lett. 2017, 58, 721. doi:10.1016/j.tetlet.2016.12.073

51. Xia, X.-F.; Zhu, S.-L.; Gu, Z.; Wang, H.; Li, W.; Liu, X.; Liang, Y.-M. J. Org. Chem. 2015, 80, 5572. doi:10.1021/acs.joc.5b00460

52. Bag, R.; Sar, D.; Punniyamurthy, T. Org. Lett. 2015, 17, 2010. doi:10.1021/acs.orglett.5b00770

53. Andia, A. A.; Miner, M. R.; Woerpel, K. A. Org. Lett. 2015, 17, 2704. doi:10.1021/acs.orglett.5b01120

54. Zhang, J.-Z.; Tang, Y. Adv. Synth. Catal. 2016, 358, 752. doi:10.1002/adsc.201500732

55. Samanta, S.; Donthiri, R. R.; Ravi, C.; Adimurthy, S. J. Org. Chem. 2016, 81, 3457. doi:10.1021/acs.joc.6b00266

56. Huang, L.; Zheng, S.-C.; Tan, B.; Liu, X.-Y. Org. Lett. 2015, 17, 1589 doi:10.1021/acs.orglett.5b00479

57. Li, Y.-X.; Wang, Q.-Q.; Yang, L. Org. Biomol. Chem. 2017, 15, 1338. doi:10.1039/c7ob00030h

58. Li, Y.; Zhou, X.; Zheng, G.; Zhang, Q. Beilstein J. Org. Chem. 2015, 11, 2721. doi:10.3762/bjoc. 11.293

59. Xia, X.-F.; Gu, Z.; Liu, W.; Wang, H.; Xia, Y.; Gao, H.; Liu, X.; Liang, Y.-M. J. Org. Chem. 2015, 80, 290. doi:10.1021/jo502327r

60. Wirth, T.; Singh, F. V. Synthesis by substitution of other halogens. Science of Synthesis Knowledge Updates: 2015/2; Thieme, 2015; pp 407-414.

61. Myint, Y. Y.; Pasha, M. A. Synth. Commun. 2004, 34, 4477. doi:10.1081/scc-200043180

62. Sanseverino, A. M.; de Mattos, M. C. S. Synthesis 1998, 1584 doi:10.1055/s-1998-2187

63. Courtneidge, J. L.; Lusztyk, J.; Pagé, D. Tetrahedron Lett. 1994, 35, 1003. doi:10.1016/s0040-4039(00)79950-3

64. Achar, T. K.; Maiti, S.; Mal, P. Org. Biomol. Chem. 2016, 14, 4654. doi:10.1039/c6ob00532b

65. Gottam, H.; Vinod, T. K. J. Org. Chem. 2011, 76, 974. doi:10.1021/jo102051z

66. Moorthy, J. N.; Senapati, K.; Kumar, S. J. Org. Chem. 2009, 74, 6287. doi:10.1021/jo9007892

67. Yusubov, M. S.; Drygunova, L. A.; Zhdankin, V. V. Synthesis 2004, 2289. doi:10.1055/s-2004-831175

68. Yusubov, M. S.; Yusubova, R. J.; Filimonov, V. D.; Chi, K.-W. Synth. Commun. 2004, 34, 443. doi:10.1081/scc-120027283

69. Yusubov, M. S.; Yusubova, R. Y.; Filimonov, V. D.; Chi, K.-W. Russ. J. Org. Chem. 2002, 38, 902. doi:10.1023/a:1020320011241

70. De Corso, A. R.; Panunzi, B.; Tingoli, M. Tetrahedron Lett. 2001, 42, 7245. doi:10.1016/s0040-4039(01)01509-x

71. Hokamp, T.; Storm, A. T.; Yusubov, M.; Wirth, T. Synlett 2018, 29, 415. doi:10.1055/s-0036-1589119

72. Terent'ev, A. O.; Krylov, I. B.; Borisov, D. A.; Nikishin, G. I. Synthesis 2007, 2979. doi:10.1055/s-2007-990776

73. Terent'ev, A. O.; Borisov, A. M.; Platonov, M. M.; Starikova, Z. A.; Chernyshev, V. V.; Nikishin, G. I. Synthesis 2009, 4159. doi:10.1055/s-0029-1217062

74. Wu, X.-F.; Gong, J.-L.; Qi, X. Org. Biomol. Chem. 2014, 12, 5807. doi:10.1039/c4ob00276h

75. Thottumkara, A. P.; Bowsher, M. S.; Vinod, T. K. Org. Lett. 2005, 7, 2933. doi:10.1021/ol050875o

76. Xia, X.-F.; Zhu, S.-L.; Zhang, D. Tetrahedron 2015, 71, 8517. doi:10.1016/j.tet.2015.09.040 
77. Krylov, I. B.; Kompanets, M. O.; Novikova, K. V.; Opeida, I. O.; Kushch, O. V.; Shelimov, B. N.; Nikishin, G. I.; Levitsky, D. O.; Terent'ev, A. O. J. Phys. Chem. A 2016, 120, 68. doi:10.1021/acs.jpca.5b10722

78. Rafiee, M.; Wang, F.; Hruszkewycz, D. P.; Stahl, S. S. J. Am. Chem. Soc. 2018, 140, 22. doi:10.1021/jacs.7b09744

79. Nair, V.; Augustine, A.; George, T. G.; Nair, L. G. Tetrahedron Lett. 2001, 42, 6763. doi:10.1016/s0040-4039(01)01377-6

80. Jörissen, J.; Speiser, B. Preparative Electrolysis on the Laboratory Scale. In Organic Electrochemistry, Fifth Edition: Revised and Expanded; Hammerich, O.; Speiser, B., Eds.; CRC Press, 2015; pp 265-329.

\section{License and Terms}

This is an Open Access article under the terms of the Creative Commons Attribution License

(http://creativecommons.org/licenses/by/4.0). Please note that the reuse, redistribution and reproduction in particular requires that the authors and source are credited.

The license is subject to the Beilstein Journal of Organic Chemistry terms and conditions:

(https://www.beilstein-journals.org/bjoc)

The definitive version of this article is the electronic one which can be found at: doi:10.3762/bjoc. 14.188 